Journal of Urban and Regional Analysis, vol. XII, 1, 2020, p. 53 - 72

https://doi.org/10.37043/JURA.2020.12.1.4

\title{
TOWARDS GREEN RESILIENT CITIES IN EASTERN EUROPEAN UNION COUNTRIES
}

\author{
Alexandru BĂNICA ${ }^{1,2}$, Marinela ISTRATE ${ }^{1}$, lone/ MUNTELE ${ }^{1,2}$ \\ ${ }^{1}$ Alexandru loan Cuza University of Iași, Iași, Romania \\ ${ }^{2}$ Department of lași, Romanian Academy, lași, Romania
}

\begin{abstract}
Investing in green facilities is a process of urban renewal that can transform cities by enhancing the quality of life, strengthening the local economy and reducing the environmental impact. Nevertheless, greener cities are not a guarantee for improved adaptive capacity when facing current local or global challenges. In this context, we have taken into account a series of sample cities from Central and Eastern European Union. Using the green cities typology proposed by the European Environment Agency, the present approach studies the statistical relationship between indicators of green infrastructure and different proxies for the resilience capacity and performance. The results distinguish between different types of green cities, indicating which are more resilient and, respectively, which are less resilient. The statistical relationship between the indicators shows that green infrastructures are developed in new urban areas, while the natural areas diminish the flood risk and air pollution and make cities more attractive; however, in older and higher density cities, the green is sacrificed for other uses that are considered more profitable. The conclusions highlight the contradictory characteristics in the territorial distributions of cities in relation to their green infrastructure and resilience features. The present assessment contributes to promoting an integrated vision that could be used in urban planning and in more coherent strategies for sustainable cities.
\end{abstract}

Key Words: green infrastructure, green cities clusters, resilience capacity, resilience performance, vulnerabilities, post-socialist cities.

\section{Introduction}

The conceptual framework regarding green and resilient cities

Nowadays, cities are more and more threatened by climate change and associated extreme events (drought, floods, heat waves, etc.), but they are also confronted with a mix of increasingly poignant internal challenges stemming from population growth, obsolete and inefficient urban infrastructure development, growing social inequality, increasing population mobility and other stressors (McPhearson et al. 2015).

Tackling these issues means a large range of strategies, measures and actions to be taken. lanos et al (2009) argue that any strategy for the sustainable development of a territorial system, any method, instrument or algorithm for the implementation of a policy in this field should be based on a good knowledge of the dynamics and interactions between the componens of both natural/physical environment and society. One of the main approaches that are taken into account for sustainable and resilient cities is promoting the development of urban green infrastructure (GI) and nature-based solutions (Calfapietra and Cherubini 2019). They may be defined as creative combinations of natural (green) and artificial (grey) structures able to fulfil certain resilience goals (flood mitigation, public health protection, air quality enhancement, etc.), if they are socially accepted and apply the appropriate technology (Staddon et al. 2018).

A green city is also an urban entity with clean and efficient energy, transportation, and building 
infrastructure, but also a healthier, more affordable, and more pleasant place to live, as it does not only focus on its environmental performance, but it also produces numerous social and economic benefits (Adjei Mensah 2016, EBRD 2016, Shimamoto 2019). Green infrastructure represents an interconnected network of green spaces including the urban tree canopy, urban forests, green corridors (streets and alleys) green lots, parks and protected natural areas, which provide, for the city, flood protection, cleaner air and cleaner water, and a wide range of other ecosystem services that are "green commons" (Colding and Barthel 2013, Jansson 2013, Chelleri et al. 2016). Meanwhile, it has been stated that investing in green facilities can transform cities by enhancing the quality of life, saving money, strengthening the local economy and reducing the impacts of climate change (including the high contribution of cities to climate change) (Antrobus 2011, Hammer et al. 2011).

In this context, the concept of urban resilience is highly significant and useful, through its inclusiveness and complementarity to green cities framework. In a larger definition, urban resilience is the ability of a city to absorb turbulences while maintaining its functions, structures and feedbacks (Lu and Stead 2013). It is also related to the capacity of a socio-ecological system to sustain a given set of ecosystem services in the face of uncertainty and change of a community (Ernstson 2013). Urban resilience can also be related to a set of urban ecosystems that provide benefits to urban livelihoods and well-being (McPhearson et al. 2015). They are a rather significant 'ingredient' of cities as systems and contribute to maintaining the 'metabolism' of cities by offering nature-based solutions to specific urban problems (Kennedy et al. 2011) and even to major shocks such as natural disasters. In this last case, green infrastructure should be designed to support an atypical state of operation by creating resilient purposeful systems that could sustain cities in difficult times (Hewitt et al. 2019). As far as the green infrastructure, resilience "is not just about the structures - grey, green, grey-green, etc. - that are intentionally designed or engineered, but also about how these are conceived, (co)created and integrated within complex socio-ecological-technical systems" (Staddon et al. 2018: 331). In this respect, an integrative approach is proposed within the framework of smart-greenresilient cities developed in the Eastern Asia, that seem much more suitable and better adapted to present environmental, societal and economic challenges of present times (Lau et al. 2016). Nevertheless, the limits should be acknowledged: greener cities are neither a guarantee for social equity and (sustainable) economic development, nor for a better adaptive capacity in front of current local or globalized challenges (Campbell 1996). Moreover, there is not just "good resilience" i.e. preparedness, responsiveness and adaptation to the new regional and global challenges, but there are also forms of "bad resilience", i.e. resistance to change by inheriting and propagating obsolete, inefficient and harmful structures and practices and emerging vulnerabilities (Rufat 2012).

Meanwhile, the similarities and dissimilarities among the basic features of the two concepts should be discussed (Fig. 1). A resilient city is adaptive, capable of self-organization, flexible, economically diversified and having resources (even back-up capacities) and functional components that are properly connected and integrated by an efficient governance system. It can tackle adversities and learn from past errors in managing turbulences while innovating and transforming according to the context. A green city is by itself biophilic and oriented towards a sustainable urban metabolism, promoting biodiversity, energy performance, integrated environmental management and the transition towards the circular economy. Both resilient cities and green cities are oriented towards communication and mobility, relying on a (green) infrastructure that connects the city, assuring a certain diversity and redundancy (areas without an "intensive" economic use) while innovating to reduce the ecological footprint of urban areas. As one main attribute, connectivity is taken into account both as an attribute of resilience in general, but also as an essential added value of green areas that are interlinked both functionally and physically and also linked to the surrounding green area, on an upper-scale, even to the regional ecological network (Galderisi and Treccozzi 2017). Meanwhile, multifunctionality, i.e. multiple ecological, social, and economic functions, goods and services that 
are provided by green areas, means an integrated environmental management that takes into consideration green spaces as infrastructure correlated and/or subordinated, structurally and functionally, to the other urban infrastructures (Davies et al. 2015).

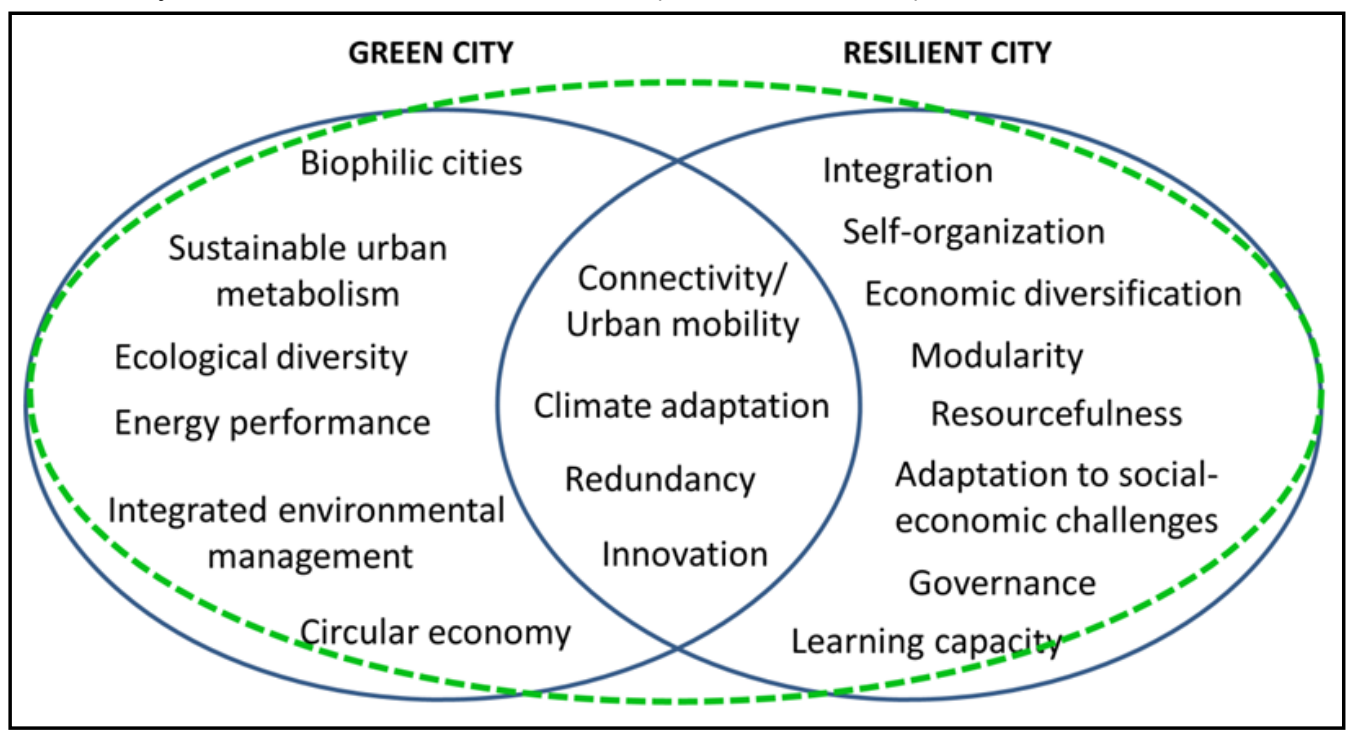

Fig. 1 - Green and/or resilient city - conceptual framework

Following an analysis of the abundant current literature, one can conclude that urban resilience is more comprehensive if it is analysed in at least five different dimensions: physical, natural (ecological), economic, institutional and social (Ribeiro and Gonçalves 2019). However, the allocation of urban space is a very important issue in planning resilient cities, as they also provide, directly or indirectly, many environmental, social-economic, aesthetic, physiological and psychological benefits (Borgström et al. 2006, Kumagai et al. 2015), which are essential attributes for inducing urban sustainability (Wolch et al. 2014, Raymond et al. 2017). There are many links between green cities performance and socio-economic indicators of resilience. As an illustration, GDP has a positive influence, population size, mainly a negative impact, while air quality influences green cities performance the most (Brilhante and Klaas 2018). The performance in education and innovation are also components of urban adaptation that can also result in implementing green assets and technologies (Lee 2018, Lv et al. 2018). Sometimes, green infrastructures can have direct economic benefits, also sustaining the overall city system resilience, for example when used for agriculture (Panagopoulos et al. 2018). There are numerous papers analysing the concept of green resilient cities and the planning issues of green areas, from the perspective of their role in improving resilience to climate change (Belčáková et al. 2019, Reinwald et al. 2019). The direct contribution of green infrastructure (integrated into the larger concept of nature-based solutions) to build general urban resilience by effective land-use planning is also demonstrated in the literature (Bush and Doyon 2019).

Socially inclusive green growth is a concept that is used by the European Commission when assessing the benefits of green infrastructure that might foster social cohesion while being the solution for certain societal challenges (European Commission 2015). Nevertheless scholars argue that green and greening strategies do not necessarily imply social inclusiveness or social sustainability, so their relations should be carefully analysed (Haase et al. 2017).

There are many issues related to greening the cities: one of the most obvious challenges for 
urban planners and managers is to balance the tension between urban green spaces and other functions with more direct benefits for different urban stakeholders (Afriyanie et al. 2018).

Even though most of the scholars and official reports state that a dense urban settlement is more environmentally friendly than urban and suburban sprawl (Millennium Ecosystem Assessment 2005), higher densities of population and buildings also put more pressure on the green areas that are sometimes replaced by other functionalities. There are also many problems related to scale mismatches or urban green and social organization in cities because of incomplete knowledge of ecosystems dynamics and institutional constraints (Borgström et al. 2006)

Finally, it is important to underline the fact that urban (green) resilience can provide a comprehensive framework for action from the part of municipalities, stressing on the impact of planning on urban ecosystems by developing a sound and effective green infrastructure able to meet environmental, social-economic and spatial challenges (Pichler-Milanovič and Foški 2015).

\section{Green resilient post-communist countries}

Urban areas in Eastern European Europe countries face numerous issues concerning different domains, not just technical-economic (lower degree of innovation, poor infrastructure, insufficient funds) and social (polarization of living conditions, lower governance level), but also environmental (inefficient green areas, increased traffic and air pollution, etc.) (Sýkora 2013, Berki 2014, Bodocan et al. 2018). The removal of restrictions after 1990 translated into a rapid heterogeneity of the Eastern European city from a social, spatial and economic point of view. The strictness of communist regulations has been replaced in most of the countries (at least until the integration in European Union) by more relaxed, inconsistent, sometimes contradictory legislation. The result consists in very large differences among cities, not only considering different Eastern European countries, but also within the same country, from one region to another (Sýkora and Bouzarovski 2012, Berki 2014).

The post-socialist city has an "original" population trend which is a combination of low birth rates, migration losses and moderate mortality leading to population ageing together with population decline (Lutz 2010). One can add that land-use instability limited the attempts at sustainable management, disfavouring peripheral urban centres, delaying the coagulation of metropolitan areas (except for the capital cities).

These challenges are only partially emerging from the communist inheritance: the Socialist period did not only promote largescale, seldom ineffective, industrial and housing projects (Nae and Turnock 2011) that are presently elements that sustain a "bad resilience" (Rufat 2012), but it also created a positive legacy: the rather extensive green space development in cities that were "lost in transition" after 1990 (Hirt 2013). The shift to the market economy and from prevalent public land ownership to private ownership encouraged an extensive and sometimes unplanned development of residential buildings and commercial spaces (Hirt 2012) often replacing green areas. Moreover, environmental problems were not a priority in the early transition, while citizens did not possess a genuine environmental culture. In this context, after 30 years from the fall of the communist regime, the post-socialist city is now struggling to increase the amount of green spaces (Badiu et al. 2019).

In the case of post-socialist cities, one assessed the fact that the accessibility to the green urban areas decreases from the inner centre to the peripheries, while green areas have the tendency to be clustered around the initial core of the city (Fuller and Gaston 2009, Sandu 2017). 
The current paper has three main objectives. Firstly, it intends to describe the state of postsocialist cities from the viewpoint of their green infrastructure, starting from the EEA (2017) typology and observing the individual attributes of all types. Secondly, the authors evaluate, in the case of each type, the resilience capacity and performance of cities using as proxies different (available) indicators. The third objective is to compare and to test the statistical correlation between green and resilience indicators in order to assess the patterns that are able to describe the complex relation between the two overlapping goals of sustainable urban planning.

\section{Methodology}

The present approach takes into consideration 95 cities and agglomerations from nine former communist countries located in the Eastern part of the EU (Fig. 2). Their population size varies from 50000 to more than 2.1 million inhabitants, while their selection was very much dependent on the availability of data. The original data and therefore the selection of cities were provided by the European Environment Agency (EEA 2017).

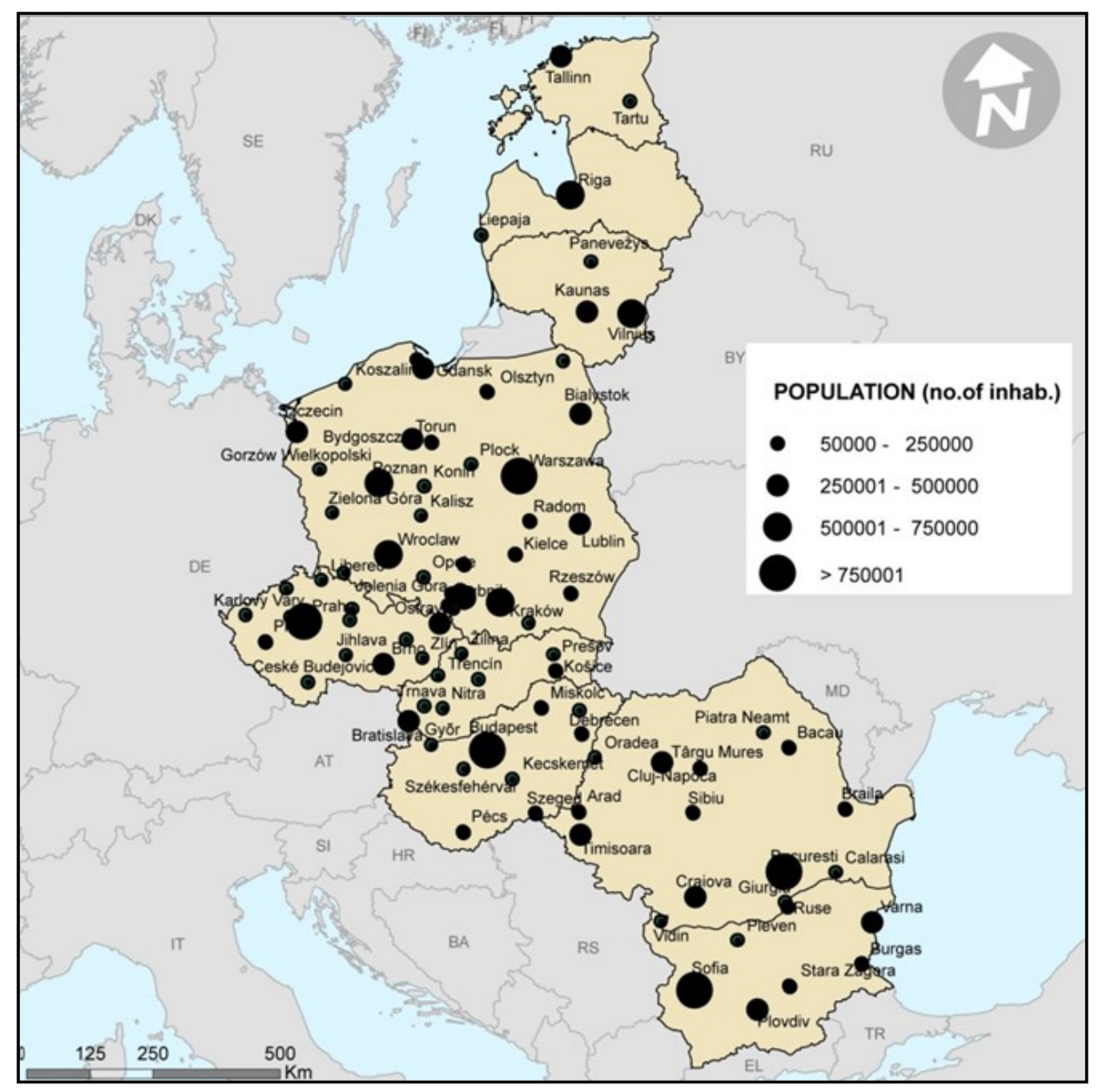

Fig. 2 - Selected cities from Eastern European Union countries 
To achieve the objectives of the present paper, three methodological steps were taken. In the first stage, the EEA typology of green cities was selected and mapped for the studied area. The weight of each type of green infrastructure in the Central and Eastern Europe (EU countries) was calculated and each category was described according to the regional context. From the eight clusters identified at EU level, six categories of cities were identified in the Eastern European Union countries and they were used for further analysis. From the components that derived the Urban Green Infrastructure (GI) typology, five indicators were selected for further evaluation of the relation with the resilience proxies: green infrastructure and effective green infrastructure, the distribution of green urban areas, their accessibility and the share of water surfaces (Table 1).

Table 1

Selected urban green indicators

\begin{tabular}{|l|l|l|l|l|}
\hline \multicolumn{1}{|c|}{ Indicator } & $\begin{array}{l}\text { Yearl } \\
\text { Period }\end{array}$ & Spatial level/Unit & Description/Aggregation & Source \\
\hline $\begin{array}{l}\text { Green } \\
\text { Infrastructure/ } \\
\text { GREEN_INF }\end{array}$ & 2006, & $\begin{array}{l}\text { CITY, METRO- } \\
\text { POLITAN/\% of } \\
\text { total land area }\end{array}$ & $\begin{array}{l}\text { Network of natural and } \\
\text { semi-natural areas with } \\
\text { other environmental features } \\
\text { designed and managed to } \\
\text { deliver a wide range of } \\
\text { ecosystem services. }\end{array}$ & $\begin{array}{l}\text { Eurostat, } \\
\text { GEOSPECS } \\
\text { State of } \\
\text { European } \\
\text { cities 2016 }\end{array}$ \\
\hline $\begin{array}{l}\text { Effective green } \\
\text { infrastructure/ } \\
\text { EFECT_GI }\end{array}$ & 2016 & $\begin{array}{l}\text { CITY/mean \% } \\
\text { from total }\end{array}$ & $\begin{array}{l}\text { The probability of finding a } \\
\text { green infrastructure element } \\
\text { in the territory or in the } \\
\text { neighbouring area. } \\
\text { Connecting (adjacent) green } \\
\text { areas in the peri-urban area } \\
\text { can effectively extend urban } \\
\text { green areas. }\end{array}$ & EEA 2017 \\
\hline $\begin{array}{l}\text { Distribution of } \\
\text { green urban } \\
\text { areas/ } \\
\text { DISTRIB_GUA }\end{array}$ & 2016 & CITY/m/ha & $\begin{array}{l}\text { The ratio of the length of the } \\
\text { urban area perimeter to the } \\
\text { urban area. Provides a } \\
\text { proxy for the equal or } \\
\text { non-equal distribution of } \\
\text { green urban areas in the } \\
\text { city. Increasing the green } \\
\text { area and distributing it more } \\
\text { evenly is an effective } \\
\text { measure in reducing the } \\
\text { undesired effects of } \\
\text { clustered urban green } \\
\text { areas. }\end{array}$ & EEA 2017 \\
\hline $\begin{array}{l}\text { Access to green } \\
\text { urban areas/ } \\
\text { SREEN_ACCE }\end{array}$ & 2012 & CITY/\% & $\begin{array}{l}\text { The accessibility of green } \\
\text { areas for the urban popula- } \\
\text { tion by city, i.e. \% people } \\
\text { living within a distance of } \\
\text { 500 metres from accessible } \\
\text { green spaces. }\end{array}$ & 2016 \\
\hline $\begin{array}{l}\text { Urban water } \\
\text { areas/WATER }\end{array}$ & 2015 & CITY/\% & $\begin{array}{l}\text { The share of urban water } \\
\text { areas (\%). }\end{array}$ & EEA 2017 \\
\hline
\end{tabular}


Secondly, urban resilience was evaluated in the case of these former-socialist countries by each category and by taking into account two types of indicators: indicators of resilience capacity (which is the general adaptability and ability to bounce back when confronting challenging events or crises) and indicators of resilience performance (meaning the actual resilience in a given period and facing a certain shock such as the economic recession). The resilience performance indicators show the dynamics before and during the economic crisis that started in 2008 were taken into account (Table 2). Here, population change - given as a factor of resilience, as high positive values show a certain urban attractiveness - was calculated for the 2001-2011 period, both at city level and at the level of Functional Urban Areas (FUA), given the suburbanization processes, and it was completed by two other indicators: change in residential, industrial and commercial areas per inhabitant (during the same period), and the change of road accessibility, given the expected outcomes due to the TEN-T policy regarding transport networks.

Resilience capacity was estimated using as proxies a variety of rather 'static' indicators (absolute values for a certain year, after the end of the economic crisis) in illustrating several categories of resilience: social-demographic (weighted population density of cities, elder population, tertiary education), economic (such as GDP per capita and number of patents), physical (residential, industrial and commercial areas per inhabitant, road accessibility, share of old and new buildings). Also, certain shocks and territorial vulnerabilities that can decrease resilience capacities (or increase it if low values are registered) were also included in the analysis (air pollution - by taking into account two main urban pollutants: $\mathrm{PM}_{10}$ and $\mathrm{NO}_{2}$, and flood risk).

The constraints of the approach are linked to the lack of more comprehensive data at city level, but, even so, the multiple indicators taken into account can give a general idea on the adaptive processes within the studied area. Given the missing indicators for certain resilience domains, no aggregated index was proposed, but rather multiple correlations were preferred in order to draw some conclusions regarding the complex relationship between all the variables in the urban context.

As the existing scientific literature argues that the green infrastructure has the capacity to induce a higher resilience capacity, the present empirical approach tries to test this assumption. The selected proxies for green cities were scaled and normalized using the minmax rescale scheme and they were included as dependent variables in the linear regression in order to highlight the statistical relationship between green and resilience indicators.

\section{Results and Discussion}

\section{Assessing Green Infrastructure (GI) clusters for the study area}

The current work has as a starting point the Urban Green Infrastructure (GI) typology made by the European Environment Agency that was intended to be a contribution for the assessment/ benchmarking of environmental performance in the case of EU cities regarding $\mathrm{GI}$.

Nine parameters were taken into account: share of green urban areas (GUAs), degree of soil sealing, distribution of GUAs, effective GI, hotspot ratio, terrestrial urban blue areas, lowdensity areas, the share of urban forest and the share of Natura 2000 sites (EEA 2017). These indicators were included in a cluster analysis, so that 8 types of cities emerged (Table 3 ). In our paper, we only took into account the post-socialist cities from Eastern and Central Europe in order to have a more in-depth view on their characteristics in relation to the indicators of urban resilience and vulnerability. Only six out of the eight types of cities identified at EU level are also found in CEE countries (Fig. 3). 
Selected Urban Resilience-Vulnerability Indicators

\begin{tabular}{|c|c|c|c|c|c|c|}
\hline Indicator & Acronym & \begin{tabular}{|c|} 
Dimension \\
of resilienced \\
vulnerability
\end{tabular} & $\begin{array}{l}\text { Yearl } \\
\text { Peri- } \\
\text { od }\end{array}$ & $\begin{array}{c}\text { Spatial } \\
\text { level }\end{array}$ & $\begin{array}{l}\text { Description/ } \\
\text { Aggregation }\end{array}$ & Source \\
\hline \multicolumn{7}{|c|}{ RESILIENCE PERFORMANCE INDICATORS } \\
\hline $\begin{array}{l}\text { Population } \\
\text { change (1) }\end{array}$ & $\mathrm{POP}_{\mathrm{C}}^{\mathrm{CHANGE}}$ & $\begin{array}{l}\text { Social- } \\
\text { economic } \\
\text { resilience }\end{array}$ & $\begin{array}{l}2001- \\
2011\end{array}$ & CITY & $\begin{array}{l}\text { Population } \\
\text { change by } \\
\text { city, 2001- } \\
2011\end{array}$ & $\begin{array}{c}\text { Euro- } \\
\text { stat, } \\
\text { State of } \\
\text { Europe- } \\
\text { an cities } \\
2016\end{array}$ \\
\hline $\begin{array}{l}\text { Population } \\
\text { change (2) }\end{array}$ & $\begin{array}{c}\text { POP_CHANGE_ }_{\text {FUA }} \\
\text { PUA }\end{array}$ & $\begin{array}{l}\text { Social- } \\
\text { economic } \\
\text { resilience }\end{array}$ & $\begin{array}{l}2001- \\
2011\end{array}$ & FUA & $\begin{array}{l}\text { Change in } \\
\text { population } \\
\text { per functional } \\
\text { urban area }\end{array}$ & $\begin{array}{c}\text { Euro- } \\
\text { stat, } \\
\text { State of } \\
\text { Europe- } \\
\text { an cities } \\
2016\end{array}$ \\
\hline $\begin{array}{l}\text { Number of } \\
\text { patents in } \\
2009\end{array}$ & PATENTS & $\begin{array}{l}\text { Social- } \\
\text { economic } \\
\text { resilience }\end{array}$ & 2009 & METRO & $\begin{array}{l}\text { Number of } \\
\text { patents per } \\
\text { million inhab- } \\
\text { itants, by } \\
\text { metropolitan } \\
\text { areas }\end{array}$ & $\begin{array}{c}\text { JRC, } \\
\text { Urban } \\
\text { Data } \\
\text { Platform }\end{array}$ \\
\hline $\begin{array}{l}\text { Change in } \\
\text { residential, } \\
\text { industrial and } \\
\text { commercial } \\
\text { areas per } \\
\text { inhabitant }\end{array}$ & $\mathrm{BUILT}_{\overline{\mathrm{NGE}}}$ & $\begin{array}{l}\text { Physical re- } \\
\text { silience }\end{array}$ & $\begin{array}{l}2006- \\
2012\end{array}$ & CITY & $\begin{array}{c}\text { Change in } \\
\text { residential, } \\
\text { industrial and } \\
\text { commercial } \\
\text { areas per } \\
\text { inhabitant per } \\
\text { city }\end{array}$ & $\begin{array}{c}\text { Euro- } \\
\text { stat, } \\
\text { State of } \\
\text { Europe- } \\
\text { an cities } \\
2016\end{array}$ \\
\hline $\begin{array}{c}\text { Road acces- } \\
\text { sibility } \\
\text { change }\end{array}$ & $\begin{array}{c}\text { ROAD_ACCES } \\
\text { CHANGE }\end{array}$ & \begin{tabular}{|c|} 
Physical re- \\
silience
\end{tabular} & 2013 & FUA & $\begin{array}{c}\text { Expected } \\
\text { change in } \\
\text { road accessi- } \\
\text { bility due to } \\
\text { the TEN-T } \\
\text { network com- } \\
\text { pletion by } \\
\text { FUA }\end{array}$ & $\begin{array}{c}\text { State of } \\
\text { Europe- } \\
\text { an cities } \\
2016\end{array}$ \\
\hline \multicolumn{7}{|c|}{ RESILIENCE CAPACITY/VULNERABILITY INDICATORS } \\
\hline Air pollution & AIR_POLL & \begin{tabular}{|c|} 
Shocks and \\
vulnerabilities
\end{tabular} & 2014 & CITY & $\begin{array}{c}\text { The concen- } \\
\text { tration for } \\
\text { PM10 and } \\
\text { NO2, taking } \\
\text { into account } \\
\text { the limit val- } \\
\text { ues }\end{array}$ & $\begin{array}{c}\text { Euro- } \\
\text { stat, } \\
\text { State of } \\
\text { Europe- } \\
\text { an cities } \\
2016\end{array}$ \\
\hline Flood risk & FLOOD_RISK & \begin{tabular}{|c|} 
Shocks and \\
vulnerabilities
\end{tabular} & 2014 & CITY & $\begin{array}{l}\text { The category } \\
\text { of flood risk of } \\
\text { urban areas }\end{array}$ & $\begin{array}{l}\text { EEA } \\
2017\end{array}$ \\
\hline
\end{tabular}




\begin{tabular}{|c|c|c|c|c|c|c|}
\hline $\begin{array}{l}\text { GDP per } \\
\text { capita }\end{array}$ & $\begin{array}{c}\text { GDP_INHAB_ME } \\
\text { TRO }\end{array}$ & $\begin{array}{l}\text { Economic } \\
\text { resilience }\end{array}$ & 2013 & METRO & $\begin{array}{l}\text { GDP per cap- } \\
\text { ita (PPS) by } \\
\text { metro region }\end{array}$ & $\begin{array}{c}\text { Euro- } \\
\text { stat, } \\
\text { State of } \\
\text { Europe- } \\
\text { an cities } \\
2016\end{array}$ \\
\hline $\begin{array}{l}\text { Tertiary edu- } \\
\text { cation }\end{array}$ & TERT_EDU & $\begin{array}{l}\text { Social- } \\
\text { Economic } \\
\text { resilience }\end{array}$ & 2014 & METRO & $\begin{array}{c}\text { Share of pop- } \\
\text { ulation that } \\
\text { graduated } \\
\text { tertiary edu- } \\
\text { cation }\end{array}$ & $\begin{array}{c}\text { JRC, } \\
\text { Urban } \\
\text { Data } \\
\text { Platform }\end{array}$ \\
\hline $\begin{array}{l}\text { Elder popula- } \\
\text { tion }\end{array}$ & ELDER & $\begin{array}{l}\text { Social- } \\
\text { Economic } \\
\text { resilience }\end{array}$ & 2012 & METRO & $\begin{array}{c}\text { Share of pop- } \\
\text { ulation } 65 \\
\text { years and } \\
\text { older }\end{array}$ & $\begin{array}{c}\text { JRC, } \\
\text { Urban } \\
\text { Data } \\
\text { Platform }\end{array}$ \\
\hline $\begin{array}{c}\text { Weighted } \\
\text { population } \\
\text { density of } \\
\text { cities }\end{array}$ & $\begin{array}{c}\text { POP_DENS_WEI } \\
\text { GHTED }\end{array}$ & $\begin{array}{l}\text { Social- } \\
\text { Economic } \\
\text { resilience }\end{array}$ & 2014 & CITY & $\begin{array}{c}\text { Weighted } \\
\text { average den- } \\
\text { sity of all land } \\
\text { parcels that } \\
\text { make up a } \\
\text { city, with } \\
\text { each parcel } \\
\text { weighted by } \\
\text { its population }\end{array}$ & $\begin{array}{c}\text { Euro- } \\
\text { stat, } \\
\text { State of } \\
\text { Europe- } \\
\text { an cities } \\
2016\end{array}$ \\
\hline $\begin{array}{l}\text { Road acces- } \\
\text { sibility }\end{array}$ & $\begin{array}{c}\text { ROAD_ACCES }_{\text {FUA }} \\
\text { - }\end{array}$ & $\begin{array}{l}\text { Physical re- } \\
\text { silience }\end{array}$ & 2013 & FUA & $\begin{array}{l}\text { Potential road } \\
\text { accessibility }\end{array}$ & $\begin{array}{c}\text { Euro- } \\
\text { stat, } \\
\text { State of } \\
\text { Europe- } \\
\text { an cities } \\
2016\end{array}$ \\
\hline $\begin{array}{l}\text { Residential, } \\
\text { industrial and } \\
\text { commercial } \\
\text { areas per } \\
\text { inhabitant }\end{array}$ & $\underset{\text { INHABB }}{\text { RES_IND_COM_ }}$ & Physical & 2012 & CITY & $\begin{array}{c}\text { Residential, } \\
\text { industrial and } \\
\text { commercial } \\
\text { areas per } \\
\text { inhabitant }\end{array}$ & $\begin{array}{c}\text { Euro- } \\
\text { stat, } \\
\text { State of } \\
\text { Europe- } \\
\text { an cities } \\
2016\end{array}$ \\
\hline $\begin{array}{l}\text { Share of old } \\
\text { buildings }\end{array}$ & OLD_BUILD & $\begin{array}{l}\text { Physical re- } \\
\text { silience }\end{array}$ & 2011 & CITY & $\begin{array}{l}\text { Share of con- } \\
\text { structions } \\
\text { built before } \\
1945 \text { from } \\
\text { total number } \\
\text { of buildings }\end{array}$ & $\begin{array}{c}\text { JRC, } \\
\text { Urban } \\
\text { Data } \\
\text { Platform }\end{array}$ \\
\hline $\begin{array}{c}\text { Share of new } \\
\text { buildings }\end{array}$ & BNEW_BUILD & $\begin{array}{l}\text { Physical re- } \\
\text { silience }\end{array}$ & 2011 & CITY & $\begin{array}{l}\text { Share of new } \\
\text { buildings from } \\
\text { total buildings }\end{array}$ & $\begin{array}{c}\text { JRC, } \\
\text { Urban } \\
\text { Data } \\
\text { Platform }\end{array}$ \\
\hline
\end{tabular}

Green outskirts cities (Type 2) - One of the most suitable category; it has high shares of green urban areas and high values of effective green infrastructure, but a rather medium (to high) distribution of green urban areas and medium degree of soil sealing. There are only seven cities in our study area, predominantly located in the Baltic countries, Poland and the Czech Republic representing $7.37 \%$ of the selected post-socialist cities. It is not represented in South- 
Alexandru BĂNICĂ, Marinela ISTRATE, Ionel MUNTELE

\begin{tabular}{|c|c|c|c|c|c|c|}
\hline \multicolumn{7}{|c|}{ Green infrastructure city clusters/types in EU and CEE } \\
\hline Type & Name & $\begin{array}{l}\text { Number } \\
\text { of cities } \\
\text { in EU }\end{array}$ & $\%$ & $\begin{array}{l}\text { Number of } \\
\text { cities in the } \\
\text { studied } \\
\text { area }\end{array}$ & $\%$ & $\begin{array}{c}\text { Differ- } \\
\text { ence } \\
(\%)\end{array}$ \\
\hline 1 & Fragmented cities & 49 & 12.73 & 0 & 0.00 & -12.73 \\
\hline 2 & Green outskirts cities & 42 & 10.91 & 7 & 7.37 & -3.54 \\
\hline 3 & Natural cities & 9 & 2.34 & 1 & 1.05 & -1.29 \\
\hline 4 & Hotspot cities & 3 & 0.78 & 0 & 0.00 & -0.78 \\
\hline 5 & Green cities & 113 & 29.35 & 28 & 29.47 & 0.12 \\
\hline 6 & $\begin{array}{c}\text { Green-grey sealed } \\
\text { cities }\end{array}$ & 85 & 22.08 & 27 & 28.42 & 6.34 \\
\hline 7 & Forest cities & 73 & 18.96 & 30 & 31.58 & 12.62 \\
\hline 8 & Natural blue cities & 11 & 2.86 & 2 & 2.11 & -0.75 \\
\hline
\end{tabular}

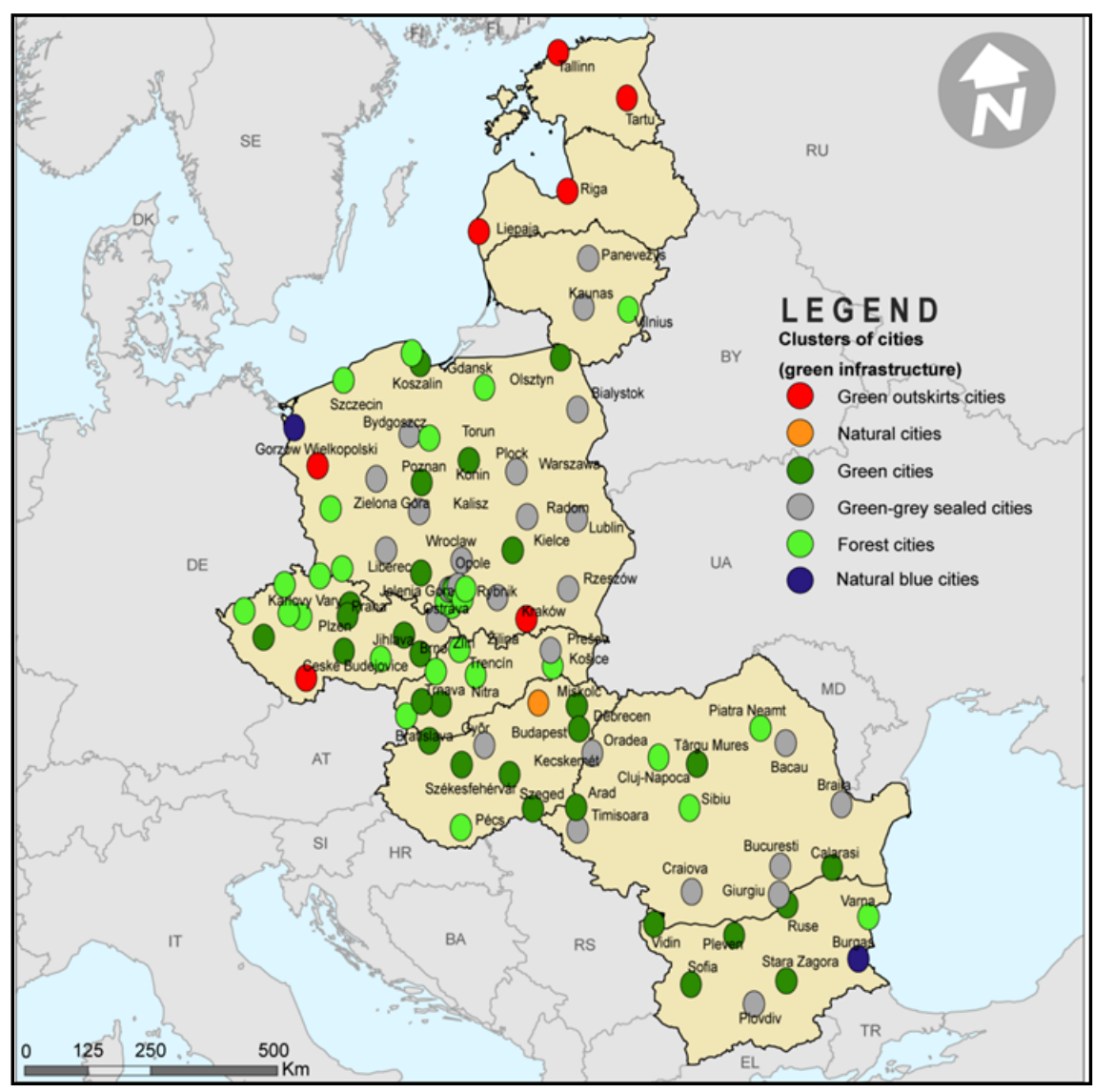

Fig. 3-Types of green infrastructure in Central and Eastern European cities Source: EEA (2017) 
Eastern Europe. Their distribution is significantly linked to the geographic position and climate correlated with the high share of forests of the nearby region and the lower population density, at least in the case of Baltic countries, but also in Ceske Budejovice and Gorzow Wielkopolski. Cracow seems to be an exception, but its inclusion among green outskirts cities is due to the large built-up area $\left(327 \mathrm{~km}^{2}\right)$ and the proximity of the forested Malopolska Plateau.

Natural cities (Type 3) - These are usually cities situated near protected areas that are also included in their administrative territory. Therefore, they have a very high proportion of green areas, Natura 2000 sites and effective green infrastructure, while the degree of soil sealing is very low. In the Eastern European Union, only one city is included, Miskolc, the third city in Hungary size wise, an old industrial centre that lost most of this profile after 1990. Presently, the city has an extensive built-up area $\left(236 \mathrm{~km}^{2}\right)$, especially in the Bukk mountains, and it capitalizes on its tourist potential (including thermal waters resources).

Green cities (Type 5) - Compared to natural cities, they also have a very high share of green areas and a low degree of soil sealing, but slightly lower values for the effective green infrastructure share. It is the most frequent type, both at European Union level and in Central Eastern Europe (about $30 \%$ of cities are included in this category), meaning that even though many cities have extensive green area, they still fail to transform them into effective green infrastructure. This cluster includes a significant number of cities in all CEE countries, except for the Baltic States. There are settlements situated in various geographic contexts, from depression areas to large rivers' valleys, sometimes including in their administrative areas (unplanned) green areas that are in the proximity.

Green-grey sealed cities (Type 6) - They also include numerous units at EU level (85), as well as at CEE level (27), a higher frequency compared to the EU average. They have a high share of soil sealing and a lower proportion of green areas, although it is relatively well distributed. Meanwhile, they have a very low share of effective green infrastructure, while they usually lack urban forests, Natura 2000 sites and they are quieter, lower populated places. Most of these cities are in Poland, Romania and Lithuania. Sometimes, the inclusion in this class is linked to the small built-up area or by the situation in densely populated areas that limits the access to green infrastructure. There are many industrial cities included in this cluster (Ostrava, Katowice, Presov, etc.). It can be considered the most representative type for Eastern Europe regarding the spatial planning with large industrial platforms at the periphery, extended areas covered by transport infrastructure and central areas that were completely regenerated (if one refers to the capitals Warsaw and Bucharest).

Forest cities (Type 7) - They have a high share of urban forests, but also a very high proportion of green areas and effective green infrastructure. Even though they have low soil sealing degrees, the share of low-density residential areas is not significant. It includes the highest share $(31.58 \%)$ of Central and Eastern European cities, almost twice the frequency at EU level, where only $18.96 \%$ of cities are in this category. It is a predominant type for mountainous regions in the Czech Republic and Slovakia, but they are represented in almost all CEE countries where the built-up area was included or extended towards the nearby forested areas. Natural blue cities (Type 8) - They have large urban blue areas and Natura 2000 sites, but only medium access to green areas in the city and its surroundings. This type includes only two cities in CEE: Szczecin, in the delta of Oder River in Northern Poland (siderurgical centre and the most important shipyard in the country, one of the most representative cities for this category at European level) and Burgas, an important port and a popular tourist area in Bulgaria - the shore of a Laguna at the Black Sea. In other parts of the EU, cities included in the same type (Venice, Cagliari, Valencia, etc.) share some common features, from the viewpoint of green-blue infrastructure, with the two cities from CEE. 


\section{Evaluating green city clusters' vulnerabilities and resilience}

The relation between green areas and infrastructure compared to city population and built-up area is directly connected to the extension of the administrative unit of the city. The more extended the built-up area, the greener or blue the city. Therefore, one can notice that the natural cities (type 3 ) and the blue cities (type 8 ) have the most extended areas. If we compare types 5, 6 and 7, which have similar average areas, the population density becomes more important: the green-grey sealed cities (type 6) have the highest population densities which is a significant pressure on the green infrastructure, while, comparatively, green cities (type 5) have a lower demographic stress, therefore, a better green performance (Fig. 4).

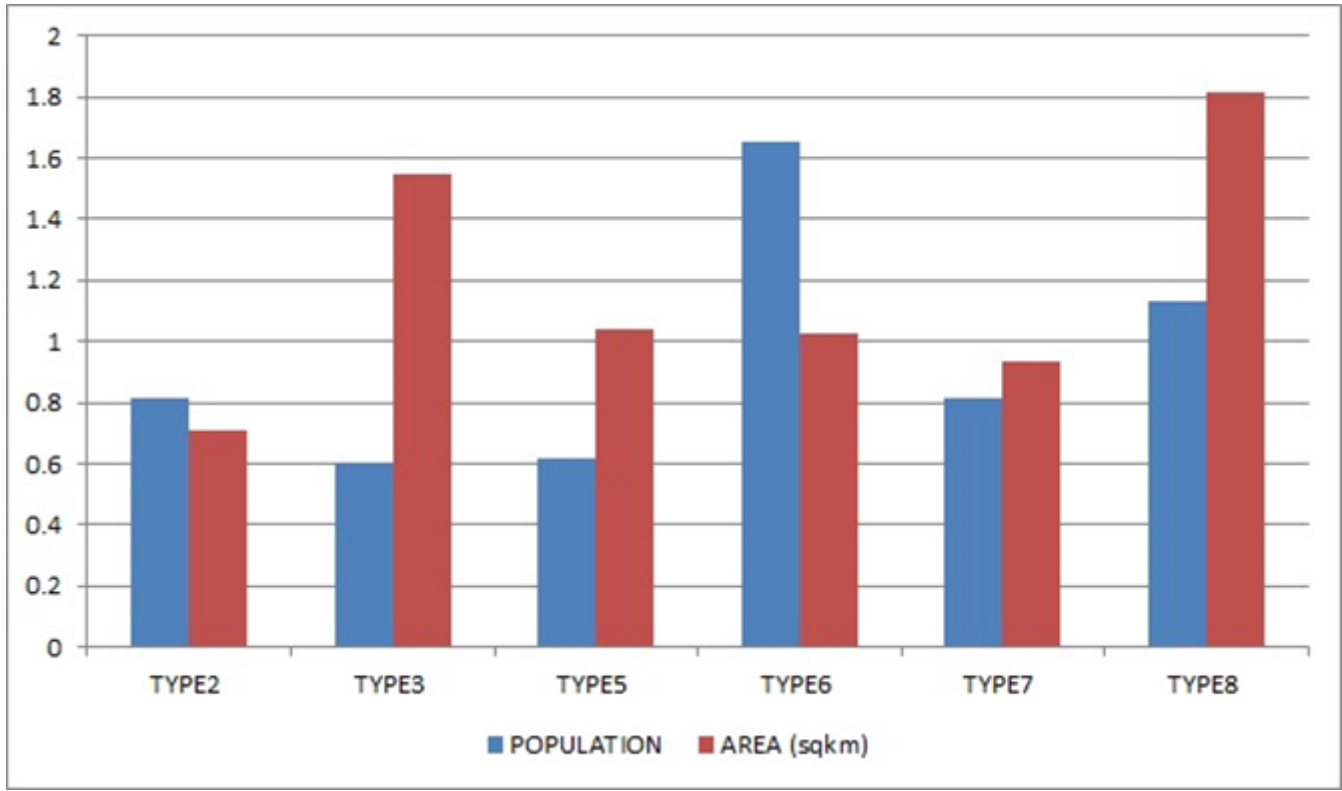

Fig. 4 - Standardised mean values of population and urban area for each type Source: State of European cities (2016)

The six clusters identified in the CEE have different profiles regarding the presence of urban infrastructure within their built-up area: although forest cities are the most numerous and seem to have a dominant position in this regard, it is also a very heterogeneous cluster with big differences between the cities that were included in (Banska Bistrica, Karlovy Vary, Sibiu or Zilina have a much more extended urban infrastructure than Torun, Prague, Bratislava or Brno). By contrast, green outskirts cities share more similarities and are, on average, better positioned. The worst performance concerning green infrastructure is that of the green-grey sealed cities (Wroclaw, Bucharest, Poznan, etc.), while the so-called "green cities" cluster is also heterogeneous and still searching for a profile that will be in accordance with its name (lowest values in Calarasi, Nitra, Trnava etc.).

If we take into account the relation between the green performance of post-socialist EU cities and the different resilience-vulnerability indicators, we can notice very complex relations that need to be studied.

Population change is an indicator that shows a certain degree of urban resilience even though the densification itself can also create vulnerabilities within the city. The general demographic 
decline after 1990 continued after 2000, in relation to both urban shrinkage and suburban population growth - the so-called Hollowing Out or "Doughnut Effect" (Wiechmann 2009). The highest values regard: the two blue cities from the CEE that are the best situated, capitalizing on their port function which was favourable in the context of transition to the market economy, but also the forest cities, with large forested areas that might be important resources for development. On the other hand, natural cities and green outskirts cities had the steepest decrease during the crisis. Although losing population, the green outskirts cities are the most economically resilient, as well as forest cities and the more industrialised green-grey sealed cities. On the contrary, the natural city was very much affected by the economic crisis and it does not perform very well economically, even though the industrial pollution remains rather high. From this point of view, green-grey sealed cities have the worst performance, while the cleanest type of cities is the green outskirts city, followed by green cities.

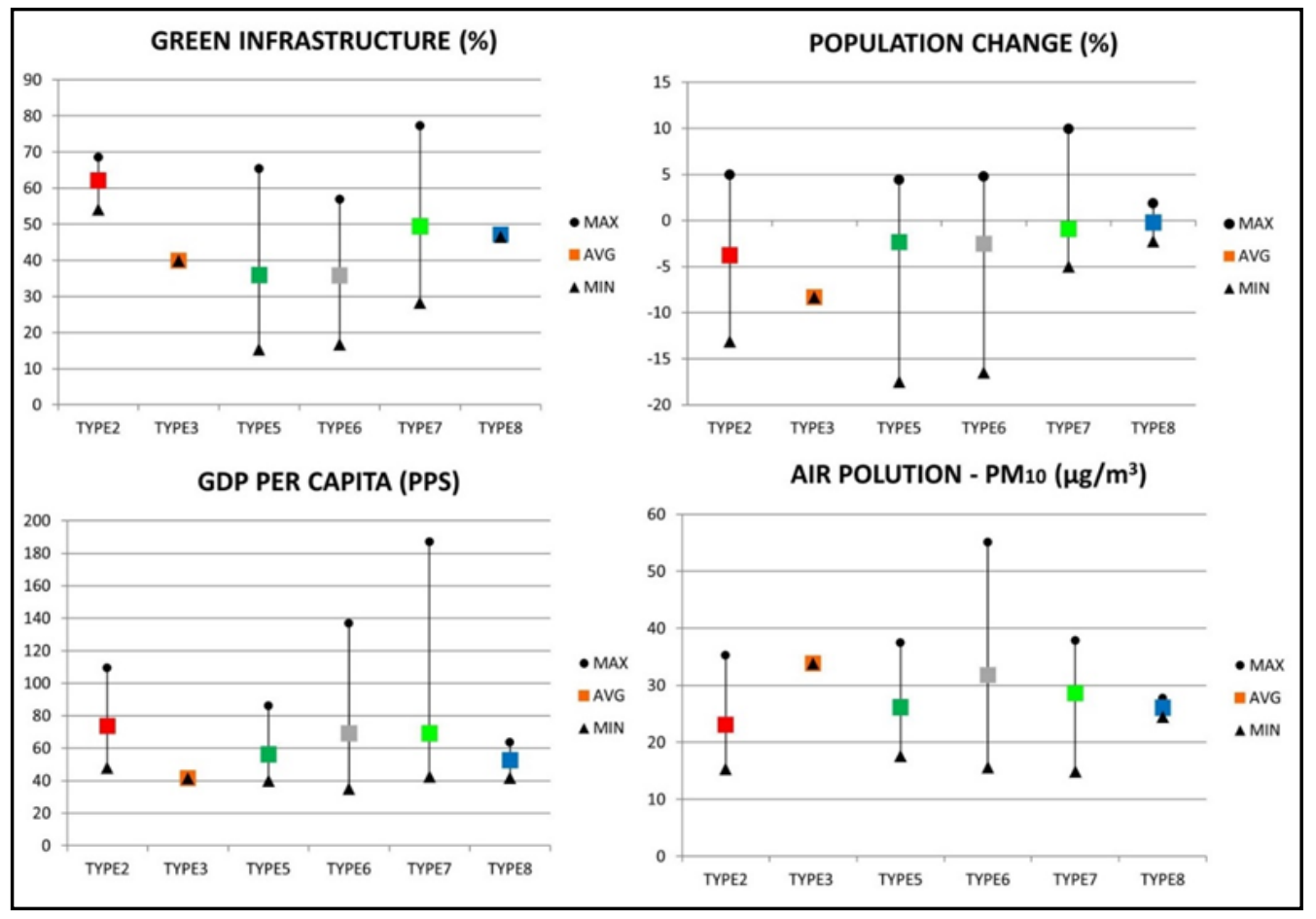

Fig. 5 - Basic indicators of green resilient cities by cluster - descriptive statistics

If we analyse the mean values for all resilience and vulnerability indicators taken into account (Fig. 5, Fig. 6) one could state the:

Green outskirts cities (Type 2) - They are performing very well in developing and applying green infrastructure strategies and in having a good economic performance during and after the crisis, together with a certain stability from the demographic and functional point of view, and a high share of population that attended tertiary education, which also relates to an increasing number of patents. They have lower population densities, but a rather efficient public transportation and the lowest pollution levels while they are less threatened by flood risks. These cities are also relatively isolated from the main EU road corridors and they have a lower 
airport accessibility (especially the Baltic countries cities) due to their peripheral situation. As a drawback, isolation in itself is not always a sign of a lack of resilience as they could be kept away from major shocks that might emerge.

Natural cities (Type 3) - They represent a cluster that includes only one city (Miskolc) within the studied area, but numerous others in Western and Southern EU (Trieste and Genova in Italy, Innsbruck in Austria, Arnhem in Netherlands). Compared to the other selected cities, Miskolc has a significant population decrease inside the city and in the functional urban area, a consequent aging of population, but also a significant loss of urban function translated in a low GDP per capita. Nevertheless, it has a rather high innovative potential (translated in the number of patents) that will presumably increase its resilience performance in the future. Presently, the city has a high level of air pollution and an extensive flood risk (although the share of water bodies in built-up areas is low).

Green cities (Type 5) - They have average values for most of the indicators, but they benefit from an increasingly high accessibility to EU road network. Although they have, comparatively, the lowest efficiency for public transport and lower education and innovation indicators, in the future, the cities forming this cluster have the potential to increase both their green infrastructures and their urban resilience capacity.

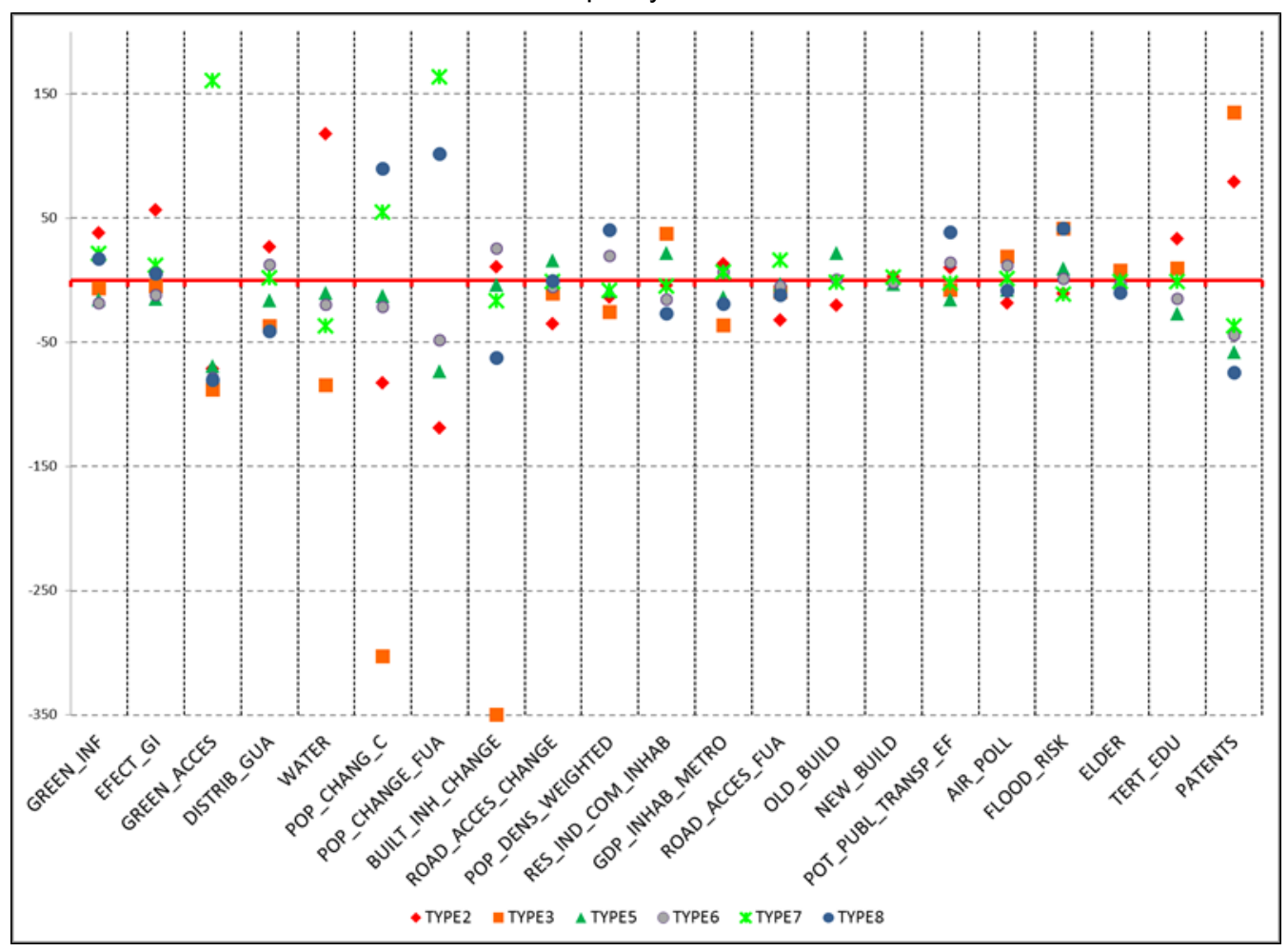

Fig. 6 - Mean values for all selected indicators by cluster

Green-grey sealed cities (Type 6) - Besides having the lowest performance in becoming green, they generally do not have a high, but a rather below average economic resilience 
performance, that is also related to the relatively lower level of education and innovation performance. Nevertheless, most of them are transforming or regenerating (the highest share of functional changes of buildings). Their densities remain rather high, despite their moderate population loss and so it is the number of vehicles that causes a high level of air pollution.

Forest cities (Type 7) - They have the highest access to green areas and they are also rather attractive urban settlements with positive population growth in the outskirts and only a small decrease within the city. The economic resilience indicators show a higher than average value, which might be correlated to a certain point to the high accessibilities to road network. They have also an average air quality and they are usually not under the risk of floods.

Natural blue cities (Type 8) - Although they have, naturally, a very good coverage with green and blue areas, they have a rather low attractiveness for economic activities in the outskirts where the population is highly decreasing. Nevertheless, they have the highest densities in the built-up areas, but a rather low economic performance, partly motivated by the lower accessibility to road and airport networks, but also by the reduced innovation capacity (lowest number of patents). The number of cars and the consequent air pollution are comparatively lower, but, due to the largest blue areas, they face a higher risk of floods.

\section{Assessing the relations between green and resilience indicators in Eastern European Union} countries

In order to better explain the relationship between the resilience indicators, the linear regression analysis shows some insightful results that can be used to describe the defining patterns of all selected cities (Table 4).

There is a slight statistical correlation between green infrastructure and population growth (0.174), which might create the assumption that cities with more green areas are generally more attractive, fact which was supported by other studies too (Kahn 2006). Moreover, one can notice significant negative correlations between population density and the presence of green areas $(-0.281)$ and effective green infrastructure $(-0.223)$. This leads to the conclusion that green cities are attractive to the population, but, once the density of people is very high, green areas are often sacrificed for other uses. The relation between green areas, population and its density was also studied, for another perspective, by other researchers, demonstrating that a higher urban pressure would produce the shrinkage of $\mathrm{Gl}$ and it would increase its level of fragmentation (Petrişor et al. 2016, Blaschke et al. 2017). The presence of the higher share of elderly population is also related to a difficult access to green areas $(-0.224)$ which might be an issue in post-communist countries, but it should be addressed accordingly in order to prepare for a sustainable urban future (Artmann et al. 2017). Meanwhile, the access to tertiary education and innovation (number of patents) correlates with an effective green infrastructure $(0.241)$ and a proper distribution of green areas $(0.183)$, which means that cities might be better planned and adapted to current necessities. In the same context, the emergence of new urban areas (by adding new buildings) is increasing the share of green areas (0.201) and of effective green infrastructure (0.296), as cities with newly constructed neighbourhoods usually integrate large green areas in order to increase general wellbeing (Ma et al. 2019). Contrariwise, a high share of old buildings is sometimes associated with a lack of open spaces with vegetation $(-0.222$ and -0.371$)$. This is explained to a certain degree by the densification processes in interstitial suburban areas that replace, in time, the open spaces and the greenways by impervious surfaces (lanoş et al. 2015).

In addition, the distribution of green urban areas is negatively correlated to the access to the road network $(-0.322)$, to high densities of buildings $(-0.275)$ and to large areas facing flood risks $(-0.371)$. Intuitively, the presence of water correlates with the flood risk, but also with the access to the main road network as well as to more densely inhabited settlements. Interestingly 
enough, there is a high negative correlation between air pollution and green infrastructure $(-0.201)$, and, even to a greater extent, with the effective green infrastructure $(-0.294)$, which is in agreement with previous studies (Kabisch and Van Den Bosch 2017), but, in the case of the selected area, it is a research topic that might be explored in future.

Meanwhile, green infrastructure reduces the flood risk $(0.291)$, which is sustained by the recent literature (Hammond et al. 2015, Berndtsson et al. 2019), but the effective green infrastructure is negatively correlated to the flood potential $(-0.281)$.

Finally, green accessibility does not significantly correlate to any of the resilience-vulnerability indicators.

\section{Linear regression results}

Table 4

\begin{tabular}{|l|l|l|l|l|l|}
\hline \multicolumn{1}{|c|}{ Dependant variables } & $\begin{array}{l}\text { GREEN_ } \\
\text { INF }\end{array}$ & $\begin{array}{c}\text { EFECT_ } \\
\text { GI }\end{array}$ & $\begin{array}{l}\text { GREEN_ } \\
\text { ACCES }\end{array}$ & $\begin{array}{c}\text { DIS- } \\
\text { TRIB_GUA }\end{array}$ & WATER \\
\hline POP_CHANG_C & $0.171^{*}$ & -0.001 & 0.156 & 0.106 & -0.120 \\
\hline POP_CHANGE_FUA & 0.160 & 0.025 & 0.071 & 0.081 & -0.152 \\
\hline BUILT_INH_CHANGE & $-0.171^{*}$ & 0.047 & 0.041 & 0.137 & 0.018 \\
\hline ROAD_ACCES_CHANGE & -0.054 & 0.025 & -0.117 & $-0.322^{*}$ & -0.009 \\
\hline POP_DENS_WEIGHTED & $-0.281^{* * *}$ & $-0.223^{\star *}$ & -0.024 & -0.107 & $0.195^{*}$ \\
\hline RES_IND_COM_INHAB & -0.056 & -0.114 & -0.042 & $-0.274^{*}$ & -0.107 \\
\hline GDP_INHAB_METRO & 0.052 & -0.070 & 0.008 & 0.078 & 0.004 \\
\hline ROAD_ACCES_FUA & 0.083 & $-0.172^{*}$ & 0.103 & 0.050 & $-0.264^{* * *}$ \\
\hline OLD_BUILD & $-0.222^{* *}$ & $-0.371^{* * *}$ & -0.165 & 0.134 & -0.167 \\
\hline NEW_BUILD & $0.218^{* *}$ & $0.296^{* * *}$ & 0.014 & -0.077 & 0.032 \\
\hline POT_PUBL_TRANSP_EF & 0.051 & -0.007 & 0.043 & -0.020 & $0.188^{*}$ \\
\hline AIR_POLL & $-0.201^{*}$ & $-0.294^{* * *}$ & -0.118 & -0.033 & -0.113 \\
\hline FLOOD_RISK & $-0.289^{* * *}$ & $-0.281^{* * *}$ & -0.053 & $-0.372^{* * *}$ & $0.312^{* * *}$ \\
\hline ELDER & -0.068 & -0.140 & $-0.224^{* *}$ & 0.065 & $0.214^{* *}$ \\
\hline TERT_EDU & 0.169 & $0.241^{* *}$ & -0.014 & -0.001 & $0.320^{* * *}$ \\
\hline PATENTS & 0.063 & 0.083 & -0.081 & $0.183^{*}$ & 0.162 \\
\hline$R^{2}$ & $\mathbf{0 . 1 6 2}$ & $\mathbf{0 . 1 5 5}$ & $\mathbf{0 . 0 4 2}$ & $\mathbf{0 . 2 2 8}$ & $\mathbf{0 . 1 5 0}$ \\
\hline Observations & 95 & 95 & 95 & 95 & 95 \\
\hline
\end{tabular}

The statistical significance at $0.1,0.05,0.01$ level is indicated by ${ }^{*},{ }^{* *},{ }^{* * *}$

The results of the linear regression show the existence of correlations that certify the importance of green urban infrastructure, but also the irregularities of recent dynamics. Some of these can be explained by the administrative modifications of built-up areas and the lack of homogeneity in including certain uses that might be assimilated to the green infrastructure within cities (Bănică et al. 2017). The negative correlation of population density, and air pollution with green areas and the efficient green infrastructure is, in this regard, illustrative, showing the opposition between the social-economic growth/economic resilience and the greening of cities in the Eastern European Union. The fact that economic indicators, such as GDP_INHAB_METRO, are not significantly correlated to any green city indicators demonstrated, as other papers argued, the lack of sufficient integration of urban environmental issues in development actions (Bănică and Muntele 2017). 


\section{Conclusions}

The analysis of the results highlights the importance of green infrastructure in enhancing resilience (capacity and performance), and, implicitly, the existence of complementarity between the two concepts: the green and the resilient city. Beyond the inaccuracies and the low degree of comparability of the available data (due to the high differences between the builtup areas), it was possible to observe several specific patterns of evolution, consistent with the influence of some geographic or social-factors. City size does not necessarily explain the variation in green performance, but it influences it, and, at the same time, size seldom influences the resilience capacity of cities (capitals are advantaged).

The analysis of the six clusters identified in the CEE shows that, while some cities maintained a positive trend, both in environmental, but also in urban resilience indicators, others seem more fragile as they cannot sustain the greener path which they have chosen by complementary economic and socially related improvements and adaptability. In this regard, cities with green outskirts and forest cities seem to be the most resilient, while green-grey sealed cities have the lowest capacity to bounce back after a shock.

All in all, the present assessment identified, in the case of selected post-socialist countries, a rather inconsistent model of urban development: usually, the most (economically) resilient cities do not sustain resilience by also becoming greener.

There are significant differences between cities from the same country and there is a high heterogeneity within the identified clusters, but one can identify a certain gradient northwestsoutheast that involves both green and resilience capacity indicators.

In the case of selected cities in the CEE, the statistical relationship between the indicators show that, although green infrastructure (GREEN_INF) was developed in new urban areas (NEW_BUILD), the natural areas diminish the flood risk (FLOOD_RISK) and air pollution (AIR_POLL) and they make cities more attractive (POP_CHANGE), yet they are sacrificed for other uses that are considered more profitable in older (ŌLD_BUILD) or in higher density cities (POP_DENS_WEIGHTED).

There are obvious limitations to the present approach that derive mainly from the inconsistency or lack of availability of some indicators of resilience at city level. Also the lack of continuous time series data for all selected cities was a major drawback in validating the resilience performance across the physical and social-economic dimensions of resilience by considering certain shocks. The indicators that were chosen for illustrating urban resilience in relation to green infrastructure are proxies that were generally used by other scholars too, but they only partially succeeded in creating a comprehensive image in the case of each category of green cities taken into account in CEE.

Acknowledging these limitations, a broader study using long-term data series of urban resilience performance when facing certain disasters in relation to changes in green infrastructure, using the same sample of cities, would result in a clearer image of the interdependencies between greening cities and making them more resilient. Further studies could also assess, more in-depth, the relation between the two concepts at a lower geographic scale (at national and/or regional level), in order to find more detailed and comprehensive explanations and the causality mechanisms besides the general features discussed in the present paper.

Finally, it should be stated that a more integrated view on the two concepts in the decision making-process at city and metropolitan area level is highly important to make a real transition 
towards more place-specific policies and a more sustainable urban development model in Central and Eastern Europe, as being both green(er) and more resilient.

\section{Acknowledgments}

This work was supported by a grant of the Ministry of Research and Innovation, CNCS UEFISCDI, project number PN-III-P4-ID-PCCF-2016-0166, within the PNCDI III project ReGrowEU - Advancing ground-breaking research in regional growth and development theories, through a resilience approach: towards a convergent, balanced and sustainable European Union.

\section{References}

ADJEI MENSAH C. (2016), The State of Green Spaces in Kumasi City (Ghana): Lessons for other African Cities, Journal of Urban and Regional Analysis 8 (2), 159-177.

AFRIYANIE D., AKBAR R., SUROSO D. S. A. (2018), Socio-Ecological Resilience for Urban Green Space Allocation, IOP Conference Series: Earth and Environmental Science 145, 012120.

ANTROBUS D. (2011), Smart green cities: from modernization to resilience?, Urban Research \& Practice 4 (2), 207-214.

ARTMANN M., CHEN X., IOJĂ C., HOF A., ONOSE D., PONIŻY L., LAMOVŠEK A. Z., BREUSTE J. (2017), The role of urban green spaces in care facilities for elderly people across European cities, Urban Forestry \& Urban Greening 27, 203-213.

BADIU D. L., ONOSE D. A., NITĂ M. R., LAFORTEZZA R. (2019), From "red" to green? A look into the evolution of green spaces in a post-socialist city, Landscape and Urban Planning 187, 156-164.

BĂNICĂ A., ISTRATE M., MUNTELE I. (2017), Challenges for the Resilience Capacity of Romanian Shrinking Cities, Sustainability 9 (12), 2289.

BĂNICĂ A., MUNTELE I. (2017), Urban transitions and resilience of Eastern European Union cities, Eastern Journal of European Studies 8 (2), 45-69.

BELČ́ÁKOVÁ I., ŚWIĄDER M., BARTYNA-ZIELIŃSKA M. (2019), The Green Infrastructure in Cities as A Tool for Climate Change Adaptation and Mitigation: Slovakian and Polish Experiences, Atmosphere 10 (9), 552.

BERKI M. (2014), Return to the road of capitalism: Recapitulating the post-socialist urban transition, Hungarian Geographical Bulletin 63 (3), 319-334.

BERNDTSSON R., BECKER P., PERSSON A., ASPEGREN H., HAGHIGHATAFSHAR S., JÖNSSON K., LARSSON R., MOBINI S., MOTTAGHI M., NILSSON J., NORDSTRÖM J., PILESJÖ P., SCHOLZ M., STERNUDD C., SÖRENSEN J., TUSSUPOVA K. (2019), Drivers of changing urban flood risk: A framework for action, Journal of Environmental Management 240, 47-56.

BLASCHKE P., CHAPMAN R., RANDAL E., PREVAL N. (2017), Does population density affect access to and satisfaction with urban green and open spaces? A review for the Resilient Urban Futures programme strand on compact and dispersed development, New Zealand Centre for Sustainable Cities, Retrieved from: www.sustainablecities.org.nz.

BODOCAN V., BENEDEK J., RUSU R. (2018), Twenty-first-century cities: From global challenges to local responses, in: Wojciech Solarz M. (ed.), New Geographies of the Globalized World, Routledge, pp. 77-92.

BORGSTRÖM S. T., ELMQVIST T., ANGELSTAM P., ALFSEN-NORODOM C. (2006) Scale Mismatches in Management of Urban Landscapes, Ecology and Society 11 (2), 16.

BRILHANTE O., KLAAS J. (2018), Green City Concept and a Method to Measure Green City Performance over Time Applied to Fifty Cities Globally: Influence of GDP, Population Size and Energy Efficiency, Sustainability 10 (6), 2031.

BUSH J., DOYON A. (2019), Building urban resilience with nature-based solutions: How can urban planning contribute?, Cities 95, 102483. 
CALFAPIETRA C., CHERUBINI L. (2019), Green Infrastructure: Nature-Based Solutions for sustainable and resilient cities, Urban Forestry \& Urban Greening 37, 1-12.

CAMPBELL S. (1996), Green cities, growing cities, just cities?: Urban Planning and the Contradictions of Sustainable Development, Journal of the American Planning Association 62 (3), 296-312.

CHELLERI L., KUA H. W., RODRÍGUEZ SÁNCHEZ J. P., NAHIDUZZAMAN K. M., THONDHLANA G. (2016), Are People Responsive to a More Sustainable, Decentralized, and User-Driven Management of Urban Metabolism?, Sustainability 8 (3), 275.

COLDING J., BARTHEL S. (2013), The potential of 'Urban Green Commons' in the resilience building of cities, Ecological Economics 86, 156-166.

DAVIES C., HANSEN R., RALL E., PAULEIT S., LAFORTEZZA R., DE BELLIS Y., SANTOS A., TOSICS I. (2015), Green infrastructure planning and implementation: The status of European green space planning and implementation based on an analysis of selected European city-regions, Green Surge, Retrieved from: www.greensurge.eu.

ERNSTSON H. (2013), The social production of ecosystem services: A framework for studying environmental justice and ecological complexity in urbanized landscapes, Landscape and Urban Planning 109 (1), 7-17.

EUROPEAN BANK FOR RECONSTRUCTION AND DEVELOPMENT (2016), Green Cities Programme Methodology, EBRD, Retrieved from: www.ebrd.com.

EUROPEAN COMMISSION (2015), Towards an EU research and innovation policy agenda for nature-based solutions \& re-naturing cities, Publications Office of the European Union, Luxembourg.

EUROPEAN ENVIRONMENT AGENCY (2017), Urban green infrastructure, EEA, Retrieved from: www.eea.europa.eu.

FULLER R. A., GASTON K. J. (2009), The scaling of green space coverage in European cities, Biology Letters 5 (3), 352-355.

GALDERISI A., TRECCOZZI E. (2017), Green Strategies for Flood Resilient Cities: The Benevento Case Study, Procedia Environmental Sciences 37, 655-666.

HAASE D., KABISCH S., HAASE A., ANDERSSON E., BANZHAF E., BARÓ F., BRENCK M., FISCHER L. K., FRANTZESKAKI N., KABISCH N., KRELLENBERG K., KREMER P., KRONENBERG J., LARONDELLE N., MATHEY J., PAULEIT S., RING I., RINK D., SCHWARZ N., WOLFF M. (2017), Greening cities - To be socially inclusive? About the alleged paradox of society and ecology in cities, Habitat International 64, 41-48.

HAMMER S., KAMAL-CHAOUI L., ROBERT A., PLOUIN M. (2011), Cities and Green Growth: A Conceptual Framework, OECD Regional Development Working Papers 2011/08, OECD Publishing.

HAMMOND M. J., CHEN A. S., DJORDJEVIĆ S., BUTLER D., MARK O. (2015), Urban flood impact assessment: A state-of-the-art review, Urban Water Journal 12 (1), 14-29.

HEWITT E., OBERG A., CORONADO C., ANDREWS C. (2019), Assessing "green" and "resilient" building features using a purposeful systems approach, Sustainable Cities and Society $48,101546$.

HIRT S. A. (2012), Iron curtains: Gates, suburbs and privatization of space in the postsocialist city, Wiley-Blackwell, Oxford. S38.

HIRT S. (2013), Whatever happened to the (post)socialist city?, Cities 32 (S1), S29-

IANOȘ I., PEPTENATU D., ZAMFIR D. (2009), Respect for environment and sustainable development, Carpathian Journal of Earth and Environmental Sciences 4 (1), 81 93.

IANOŞ I., SîRODOEV I., PASCARIU G., HENEBRY G. (2015), Divergent patterns of built-up urban space growth following post-socialist changes, Urban Studies 53 (15), 31723188.

JANSSON Å. (2013), Reaching for a sustainable, resilient urban future using the lens of ecosystem services, Ecological Economics 86, 285-291. 
KABISCH N., VAN DEN BOSCH M. A. (2017), Urban Green Spaces and the Potential for Health Improvement and Environmental Justice in a Changing Climate, in: Kabisch N., Korn H., Stadler J., Bonn A. (eds.), Nature-Based Solutions to Climate Change Adaptation in Urban Areas. Theory and Practice of Urban Sustainability Transitions, Springer, Cham, pp. 207-220.

KAHN M. E. (2006), Green Cities: Urban Growth and the Environment, Brookings Institution Press, Washington, D.C.

KENNEDY C., PINCETL S., BUNJE P. (2011), The study of urban metabolism and its applications to urban planning and design, Environmental Pollution 159 (8-9), 1965-1973.

KUMAGAI Y., GIBSON R. B., FILION P. (2015), Evaluating long-term urban resilience through an examination of the history of green spaces in Tokyo, Local Environment: The International Journal of Justice and Sustainability 20 (9), 1018-1039.

LAU W., ROMANOS C., CHONG B. (2016), Smart green resilient, Ove Arup \& Partners Hong Kong Ltd., Hong Kong.

LEE D.-S. (2018), Towards Urban Resilience through Inter-City Networks of CoInvention: A Case Study of U.S. Cities, Sustainability 10 (2), 289.

LU P., STEAD D. (2013), Understanding the notion of resilience in spatial planning: $A$ case study of Rotterdam, The Netherlands, Cities 35, 200-212.

LUTZ W. (2010), Emerging Population Issues in Eastern Europe and Central Asia: Research Gaps on Demographic Trends, Human Capital and Climate Change, UNFPA Eastern Europe and Central Asia Regional Office, New York.

LV W.-D., TIAN D., WEI Y., XI R.-X. (2018), Innovation Resilience: A New Approach for Managing Uncertainties Concerned with Sustainable Innovation, Sustainability 10 (10), 3641.

MA B., ZHOU T., LEI S., WEN Y., HTUN T. T. (2019), Effects of urban green spaces on residents' well-being, Environment, Development and Sustainability 21, 2793-2809.

MCPHEARSON T., ANDERSSON E., ELMQVIST T., FRANTZESKAKI N. (2015), Resilience of and through urban ecosystem services, Ecosystem Services 12, 152-156.

MILLENNIUM ECOSYSTEM ASSESSMENT (2005), Ecosystems and Human Wellbeing: Synthesis, Island Press, Washington, D.C.

NAE M., TURNOCK D. (2011), The new Bucharest: Two decades of restructuring, Cities 28 (2), 206-219.

PANAGOPOULOS T., JANKOVSKA I., DAN M. B. (2018), Urban green infrastructure: The role of urban agriculture in city resilience, Urbanism. Arhitectură. Construcţii 9 (1), 55-70.

PETRIŞOR A.-I., ANDRONACHE I. C., PETRIŞOR L. E., CIOBOTARU A.-M., PEPTENATU D. (2016), Assessing the Fragmentation of the Green Infrastructure in Romanian Cities Using Fractal Models and Numerical Taxonomy, Procedia Environmental Sciences 32, 110-123.

PICHLER-MILANOVIČ N., FOŠKI M. (2015), Green Infrastructure and Urban Revitalisation in Central Europe: Meeting Environmental and Spatial Challenges in the Inner City of Ljubljana, Slovenia, Urbani Izziv 26 (S), S50-S64.

RAYMOND C. M., FRANTZESKAKI N., KABISCH N., BERRY P., BREIL M., NITA M. R., GENELETTI D., CALFAPIETRA C. (2017), A framework for assessing and implementing the co-benefits of nature-based solutions in urban areas, Environmental Science \& Policy 77, 15-24.

REINWALD F., RING Z., KRAUS F., KAINZ A., TÖTZER T., DAMYANOVIC D. (2019), Green Resilient City - A framework to integrate the Green and Open Space Factor and climate simulations into everyday planning to support a green and climate-sensitive landscape and urban development, IOP Conference Series: Earth and Environmental Science 323, 012082.

RIBEIRO P. J. G., GONÇALVES L. A. P. J. (2019), Urban resilience: A conceptual framework, Sustainable Cities and Society 50, 101625.

RUFAT S. (2012), Existe-t-il une "mauvaise» résilience?, in: Djament-Tran G., Reghezza-Zitt M. (coord.), Résiliences urbaines: Les villes face aux catastrophes, Le Manuscrit, Paris, pp. 195-241.

SANDU A. (2017), To be or not to be green? The challenge of urban sustainable 
development in the post-socialist city. Case study: Central and Eastern Europe, 17th International Multidisciplinary Scientific GeoConference SGEM 17 (23), 799-806.

SHIMAMOTO K. (2019), Empirical Analysis on the Determinants of Urban Parks, Journal of Urban and Regional Analysis 11 (1), 87-102.

STADDON C., WARD S., DE VITO L., ZUNIGA-TERAN A., GERLAK A. K., SCHOEMAN Y., HART A., BOOTH G. (2018), Contributions of green infrastructure to enhancing urban resilience, Environment Systems and Decisions 38, 330-338.

SYKORA L. (2013), Post-socialist City, WARE Waterfront Regeneration, Bratislava.

SÝKORA L., BOUZAROVSKI S. (2012), Multiple Transformations: Conceptualising the Post-communist Urban Transition, Urban Studies 49 (1), 43-60.

WIECHMANN T. (2009), Conversion strategies under uncertainty in post-socialist shrinking cities - the example of Dresden in Eastern Germany, in: Pallagst K., Aber J., Audirac I., Cunningham-Sabot E., Fol S., Martinez-Fernandez C., Moraes S., Mulligan H., VargasHernandez J., Wiechmann T., Wu T., Rich J. (eds.), The Future of Shrinking Cities-Problems, Patterns and Strategies of Urban Transformation in a Global Context, Center for Global Metropolitan Studies, Berkeley, pp. 5-16.

WOLCH J. R., BYRNE J., NEWELL J. P. (2014), Urban green space, public health, and environmental justice: The challenge of making cities 'just green enough', Landscape and Urban Planning 125, 234-244.

Initial submission: 14.11.2019

Revised submission: 20.02.2020

Final acceptance: 24.02 .2020

Correspondence: Faculty of Geography and Geology, Alexandru loan Cuza University of lași, 20A Carol I Blv., 700505, lași, Romania.

Email: alexandrubanica@yahoo.com 
